\title{
Novel nitrogen-fixing Acetobacter nitrogenifigens sp. nov., isolated from Kombucha tea
}

\author{
Debasree Dutta and Ratan Gachhui
}

Correspondence
Ratan Gachhui
ratangachhui@yahoo.com

\author{
Department of Life Science and Biotechnology, Jadavpur University, Kolkata 700032, West \\ Bengal, India
}

\begin{abstract}
The four nitrogen-fixing bacteria so far described in the family Acetobacteraceae belong to the genera Gluconacetobacter and Acetobacter. Nitrogen-fixing bacterial strain $\mathrm{RG}_{1}{ }^{\top}$ was isolated from Kombucha tea and, based on the phylogenetic analysis of 16S rRNA gene sequence which is supported by a high bootstrap value, was found to belong to the genus Acetobacter. Strain RG1 ${ }^{\top}$ differed from Acetobacter aceti, the nearest member with a 16S rRNA gene sequence similarity of 98.2 \%, and type strains of other Acetobacter species with regard to several characteristics of growth features in culture media, growth in nitrogen-free medium, production of $\gamma$-pyrone from glucose and dihydroxyacetone from glycerol. Strain $\mathrm{RG} 1^{\top}$ utilized maltose, glycerol, sorbitol, fructose, galactose, arabinose and ethanol, but not methanol as a carbon source. These results, along with electrophoretic mobility patterns of nine metabolic enzymes, suggest that strain $\mathrm{RG}_{1}{ }^{\top}$ represents a novel nitrogen-fixing species. The ubiquinone present was Q-9 and DNA G + C content was $64 \cdot 1$ mol\%. Strain $\mathrm{RG}^{\top}{ }^{\top}$ exhibited a low value of 2-24\% DNA-DNA relatedness to the type strains of related acetobacters, which placed it as a separate taxon. On the basis of this data, the name Acetobacter nitrogenifigens sp. nov. is proposed, with the type strain RG1 ${ }^{\top}$ $\left(=\right.$ MTCC $6912^{\top}=$ LMG $\left.23498^{\top}\right)$.
\end{abstract}

Endophytic bacteria colonize the internal tissues of the host plant for mutual benefits. The nitrogen-fixing endophyte Gluconacetobacter diazotrophicus has been found to be associated with sugarcane, pineapple, cameroon grass, sweet potato, mango and banana (Muthukumarasamy et al., 2002), while Gluconacetobacter azotocaptans and Gluconacetobacter johannae inhabit coffee plants (FuentesRamírez et al., 2001) and provide host plants with useful fixed nitrogen and growth stimulants. The first report of the occurrence and association of nitrogen-fixing Acetobacter peroxydans along with $G$. diazotrophicus inhabiting cultivated wetland rice varieties demonstrated the presence of nitrogen-fixing property in the genus Acetobacter (Muthukumarasamy et al., 2005). Based on the striking resemblance of the high sugar and low $\mathrm{pH}$ habitats of sugarcane and Kombucha tea (Blanc, 1996), we explored and isolated a nitrogen-fixing strain $\mathrm{RG}^{\mathrm{T}}$ belonging to the genus Acetobacter of the family Acetobacteraceae. This family has been divided into eight genera; Acetobacter, Gluconacetobacter, Gluconobacter, Acidomonas, (Yamada

\section{Abbreviation: MLEE, multilocus enzyme electrophoresis.}

The GenBank/EMBL/DDBJ accession numbers for the $16 \mathrm{~S}$ rRNA gene and nifH gene sequences of strain $R G 1^{\top}$ are $A Y 669513$ and AY952470, respectively.

A MLEE dendrogram showing the relationships between Acetobacter nitrogenifigens sp. nov. and type strains of closely related Acetobacter species is available as a supplementary figure in IJSEM Online. et al., 1997), Asaia (Yamada et al., 2000), Kozakia (Lisdiyanti et al., 2002), Saccharibacter (Jojima et al., 2004) and Swaminathania (Loganathan \& Nair, 2004). The genus Acetobacter comprises, at present, 15 validly described species that were delineated mainly on the basis of DNADNA relatedness and phylogenetic relationships (Sokollek et al., 1998; Lisdiyanti et al., 2000, 2001; Cleenwerck et al., 2002; Silva et al., 2006). This report of the isolation of nitrogen-fixing strain $\mathrm{RG}^{\mathrm{T}}$ from the novel source Kombucha tea is only second in the genus Acetobacter after A. peroxydans (Muthukumarasamy et al., 2005).

We present morphological, biochemical and genetic evidence which indicates that this isolate represents a novel nitrogen-fixing species within the genus Acetobacter isolated from a novel source. We propose the name Acetobacter nitrogenifigens for the $\mathrm{RG}^{\mathrm{T}}$ isolate.

Aliquots of Kombucha mat suspension, after teasing the mat apart in the soup, were spread on to LGI $(0.06 \%$ $\mathrm{KH}_{2} \mathrm{PO}_{4}, 0 \cdot 02 \% \mathrm{~K}_{2} \mathrm{HPO}_{4}, 0 \cdot 02 \% \mathrm{MgSO}_{4}, 0 \cdot 002 \% \mathrm{CaCl}_{2}$, $0 \cdot 001 \% \mathrm{FeCl}_{3}, 0 \cdot 0002 \% \mathrm{Na}_{2} \mathrm{MoO}_{4}, 10 \%$ sucrose, $\mathrm{pH} 4 \cdot 5$; Cavalcante \& Döbereiner, 1988) agar plates containing $150 \mathrm{mg}$ cycloheximide $\mathrm{l}^{-1}$ (Jimenez-Salgado et al., 1997) and $150 \mathrm{mg}$ nystatin $\mathrm{l}^{-1}$. Plates were incubated at $30{ }^{\circ} \mathrm{C}$ for 5 days. The bacterial isolate was purified by repeated streaking on to LGI plates, which have no combined nitrogen source. Gas tight vials of bacteria-inoculated LGI medium (under microaerophilic environment, without 
shaking) were assayed for acetylene reduction activity (Stal, 1988). Nitrogenase-positive isolates were selected for further characterization. Nitrogen-fixing bacterial strain $\mathrm{RG}^{\mathrm{T}}$ was isolated. Other reference strains and the novel isolates were grown in mannitol broth for further study. Colony morphology was examined on LGI agar plates and on potato agar plates containing $10 \%$ sucrose. Various phenotypic and morphological studies were performed using standard techniques described elsewhere (Cavalcante \& Döbereiner, 1988; Caballero-Mellado et al., 1995; Jimenez-Salgado et al., 1997; Cleenwerck et al., 2002). Isoprenoid quinone of the isolate was extracted with chloroform/methanol $[2: 1,(\mathrm{v} / \mathrm{v})]$, and then purified by TLC on silica gel $60 \mathrm{~F}_{254}(20 \times 20 \mathrm{~cm}$; Merck) by using benzene as the developing solvent. Quinones recovered from the TLC plates were dissolved in acetone and analysed by HPLC (Lu et al., 1999). The HPLC system was equipped with a reverse-phase column [Luna $5 \mathrm{U}$ C18 (2) 100A, $250 \times 4.6 \mathrm{~mm}$; Phenomenex $]$ and a mixture of methanol/2-propanol $[2: 1,(\mathrm{v} /$ v)] was used as the mobile phase at a flow rate of $1 \mathrm{ml} \mathrm{min}^{-1}$. Types of quinone were identified by absorption at $275 \mathrm{~nm}$ and compared with coenzymes Q-9 and Q-10 standards from Sigma-Aldrich. Ubiquinone Q-9 was present in strain RG1 ${ }^{\mathrm{T}}$ presence of this ubiquinone type in the genus Acetobacter (Cleenwerck et al., 2002). The type strain $\mathrm{RG}^{\mathrm{T}}$ deviated biochemically and morphologically from other species of the genus Acetobacter as shown in Table 1.

A $1451 \mathrm{bp}$ fragment of $16 \mathrm{~S}$ rRNA gene was PCR amplified with bacteria-specific primers fD1 and rD1 (Weisburg et al., 1991) using Taq polymerase and genomic DNA from strain $\mathrm{RG}^{\mathrm{T}}$ as template. The nucleotide sequence was similar to the extent of $98.2 \%$ with Acetobacter aceti, 97.7\% with Acetobacter estunensis, 97.4\% with Acetobacter indonesiensis, $97 \cdot 2 \%$ with Acetobacter tropicalis, $97 \cdot 2 \%$ with Acetobacter oeni, 97.1\% with Acetobacter cibinongensis, 97.0\% with Acetobacter cerevisiae, $97.0 \%$ with Acetobacter malorum, 96.9\% with Acetobacter orleansis, 96.6\% with Acetobacter orientalis and $97.0 \%$ with Acetobacter syzygii after performing a similarity search with FASTA (ungapped). The phylogenetic tree (Fig. 1) was deduced using MEGA version 3.1 (Kumar et al., 2004) software after multiple alignment of 16S rRNA gene sequences of other acetic acid bacteria with CLUSTAL W (Thompson et al., 1994). Distances (distance options according to the Kimura two-parameter model) and clustering with the neighbour-joining method was determined by using bootstrap values (Felsenstein, 1985) based on 100 replications. Two subclusters were evident in the genus Acetobacter. one composed of Acetobacter pomorum, Acetobacter pasteurianus, A. syzygii, Acetobacter lovaliensis and A. peroxydans and the other included Acetobacter aceti and other acetobacters along with the novel nitrogen-fixing strain $\mathrm{RG}^{\mathrm{T}}$. The clustering of strain $\mathrm{RG}^{\mathrm{T}}$ with $A$. aceti was further confirmed by the formation of dihydroxyacetone from glycerol by both strains $\mathrm{RG}^{\mathrm{T}}$ and A. aceti ATCC $15973^{\mathrm{T}}$.

Cell extracts were prepared for multilocus enzyme electrophoresis (MLEE) and run on a starch gel as described and fitted with the previous observations that showed the

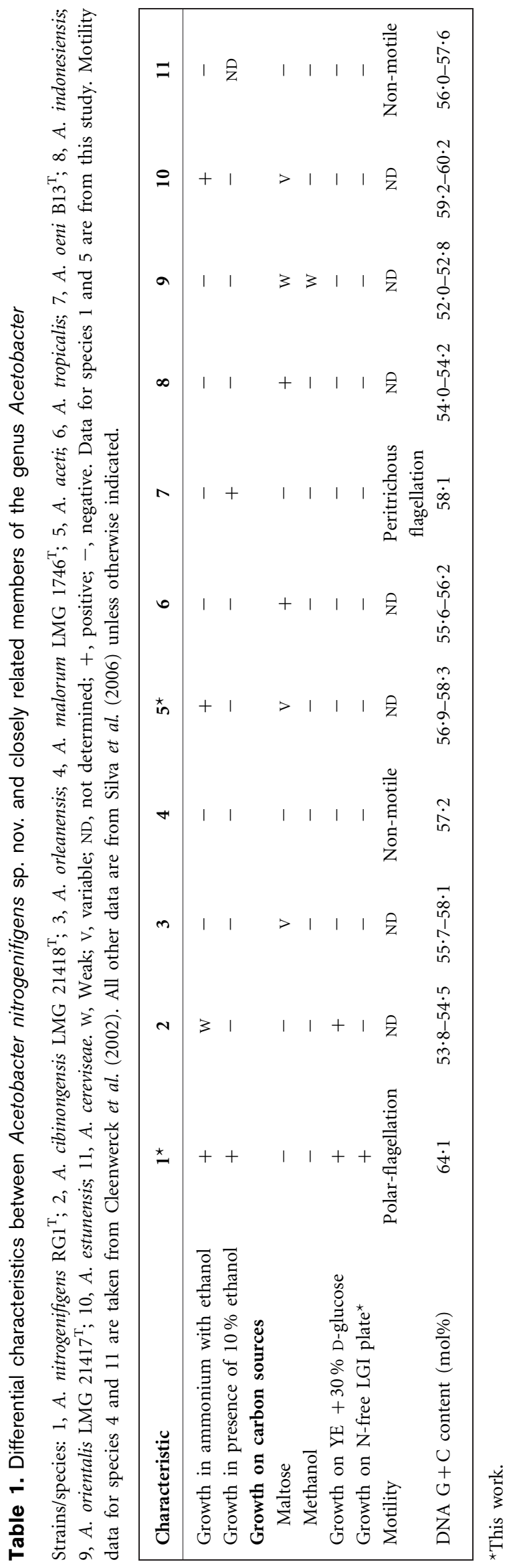




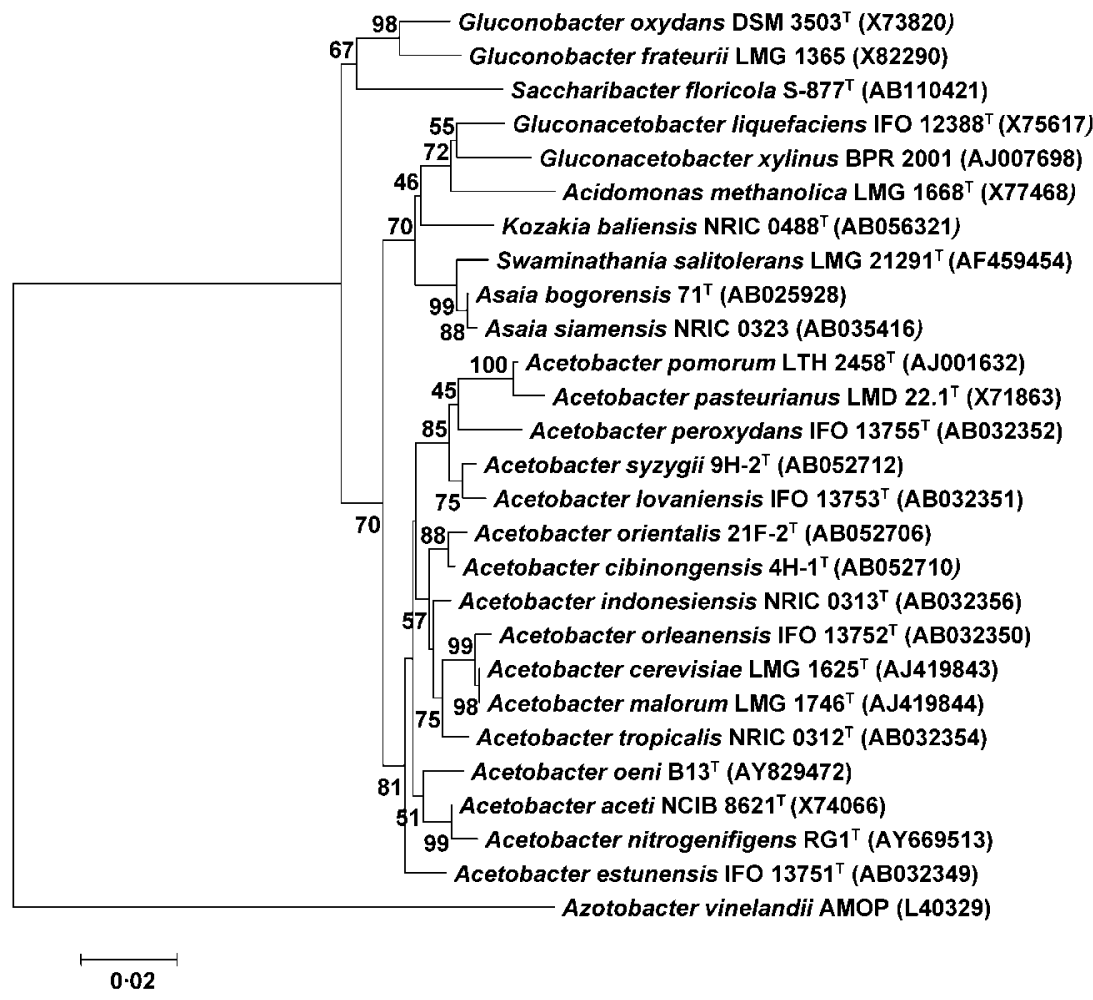

Fig. 1. Phylogenetic relationships of acetic acid bacteria based on 16S rRNA gene sequences involving Acetobacter nitrogenifigens sp. nov. and other related species of the family Acetobacteraceae. Numbers at nodes indicate bootstrap values derived from 100 replications. GenBank accession numbers of 16S rRNA gene sequences are indicated in parentheses. Bar, 2 substitutions per 100 nucleotides.

previously (Selander et al., 1986; Caballero-Mellado \& Martínez-Romero, 1994). A. cibinongensis JCM $11196^{\mathrm{T}}, A$. orleansis $\mathrm{LMG} 1583^{\mathrm{T}}$, A. malorum $\mathrm{LMG} 1746^{\mathrm{T}}$, A. aceti ATCC $15973^{\mathrm{T}}$, A. tropicalis LMG $19825^{\mathrm{T}}$, A. oeni $\mathrm{B} 13^{\mathrm{T}}$, A. orientalis JCM $11195^{\mathrm{T}}, A$. indonesiensis LMG $19824^{\mathrm{T}}$, A. estunensis LMG $1626^{\mathrm{T}}$ and A. cerevisiae LMG $1625^{\mathrm{T}}$ were included as reference strains. The relationships among non-nitrogen-fixing species of Acetobacter and $\mathrm{RG}^{\mathrm{T}}$ are illustrated by the dendrogram (Supplementary Fig. S1 available in IJSEM Online) derived by program ETMEGA (T. S. Whittam; http:/foodsafe.msu.edu/whittam/programs/ index.html) and MEGA version 3.1 software based on the electrophoretic mobility of nine metabolic enzymes, indophenol oxidase, alcohol dehydrogenase, isocitrate dehydrogenase, glucose-6-phosphate dehydrogenase, xanthine dehydrogenase, leucine dehydrogenase, lysine dehydrogenase, hexokinase and esterase. In MLEE, strain $\mathrm{RG}^{\mathrm{T}}$ exhibited highest similarity to A. aceti ATCC $15973^{\mathrm{T}}$, which is in agreement with its phylogenetic position (Fig. 1). Analysis of the dendrogram revealed that strain $\mathrm{RG}^{\mathrm{T}}$ formed a unique branch with $A$. aceti ATCC $15973^{\mathrm{T}}$ that deviated at a genetic distance of more than $0 \cdot 5$. This value has been used as a criterion to suggest species limits (Selander et al., 1985; Musser et al., 1987). Thus, MLEE results strongly support the existence of strain $R G 1^{\mathrm{T}}$ as a novel Acetobacter species.

The nitrogenase enzyme complex, responsible for nitrogenfixation, is composed of nifHDK and other gene fragments. A 336 bp region encoding dinitrogenase reductase, nifH, was amplified from strain $R G 1^{\mathrm{T}}$ using degenerate primers
19F and 407R (Franke et al., 1998) and sequenced. Presence of nifH gene further confirmed the nitrogen-fixing ability of strain $R G 1^{\mathrm{T}}$.

To determine genomic relatedness of the novel isolate, dot-blot hybridization experiments were carried out with DIG-labelled DNA as described previously (Labrenz et al., 2000) using the detection kit from Roche Applied Sciences and following the manufacturer's instructions. Colorimetric quantification of dot intensities was done using the Molecular Analyst software (Bio-Rad) by determining mean pixel densities in equal sized circles. A genomic DNA probe was prepared from the novel strain $\mathrm{RG}^{\mathrm{T}}$, digested with EcoRI and run on $0.7 \%$ agarose gel. Total DNA digests were transferred from gels to nylon membrane by Southern blotting. Hybridization was performed at a temperature of $75^{\circ} \mathrm{C}$ for $16 \mathrm{~h}$ and the membrane was washed under high stringency conditions (twice with $2 \times \mathrm{SSC} / 0 \cdot 1 \% \mathrm{SDS}$ at room temperature for $10 \mathrm{~min}$; once with $0 \cdot 1 \times \mathrm{SSC} / 0 \cdot 1 \%$ SDS at $75^{\circ} \mathrm{C}$ for $\left.15 \mathrm{~min}\right)$. A low level of genomic DNA relatedness (DNA-DNA hybridization values less than $50 \%$ ) was observed between the phylogenetically closest species and genera. Strain $\mathrm{RG}^{\mathrm{T}}$ showed low DNA-DNA relatedness with the type strains of $A$. oeni (24\%), A. acet $i$ $(22 \%)$, A. cerevisiae (19\%), A. cibinongensis $(18 \cdot 91 \%)$, A. orientalis $(18 \cdot 9 \%), A$. estunensis (11\%), A. orleansis $(10 \cdot 37 \%)$, A. malorum $(7 \cdot 31 \%)$, A. indonesiensis $(3 \cdot 71 \%)$ and $A$. tropicalis (2\%).

Although the limitations of $16 \mathrm{~S}$ rRNA gene sequencing to differentiate closely related species have been documented 
(Fox et al., 1992), it is suggested that strains sharing greater than $97 \%$ similarity might belong to the same species but a lower similarity value could form the basis of delineation of bacterial species (Stackebrandt \& Goebel, 1994). Also a DNA-DNA relatedness level below $70 \%$ indicates a distinct species (Stackebrandt \& Goebel, 1994). In the present study, these considerations were consistent with both the $16 \mathrm{~S}$ rRNA gene sequence similarity levels and the low levels of DNA-DNA relatedness exhibited within the Acetobacter species. The genetic distance of different closely related acetobacters involving strain $\mathrm{RG1}^{\mathrm{T}}$ was found to be greater than 0.5 in all comparisons and such a distance indicates a novel species; hence strain $\mathrm{RG}^{\mathrm{T}}$ represent a novel species of the genus Acetobacter.

In view of low physiological, biochemical, phylogenetic and genetic similarities among different closely related members of the genus Acetobacter, we recommend that nitrogenfixing strain $\mathrm{RG}^{\mathrm{T}}$ described here should be assigned to a novel species of the genus Acetobacter, for which the name Acetobacter nitrogenifigens sp. nov. is proposed.

\section{Description of Acetobacter nitrogenifigens sp. nov.}

Acetobacter nitrogenifigens (ni.tro.gen.i'fi.gens. N.L. n. nitrogenium nitrogen; L. part. adj. figens fixing; N.L. part. adj. nitrogenifigens nitrogen-fixing).

Cells are straight rods with rounded ends, approximately $1 \cdot 5-2 \cdot 0 \mu \mathrm{m}$ in length and $0 \cdot 1-0 \cdot 2 \mu \mathrm{m}$ in width and occur singly or in chains. These Gram-negative bacteria are motile with polar flagellation, catalase-positive and oxidasenegative. Growth occurs on nitrogen-free LGI plates at $30{ }^{\circ} \mathrm{C}$, but not at $37^{\circ} \mathrm{C}$ and in LGI broth under microaerophilic conditions. After incubation for 5 days, colonies grown on LGI plates are smooth, round, glistening, transparent and $2-3 \mathrm{~mm}$ in diameter, while dark-yellow colonies are formed on LGI agar supplemented with $0.001 \%$ bromothymol blue. Colonies on potato agar are light brown after 5 days of incubation, but the intensity increases after 10 days. Strains are aerobic and fix atmospheric nitrogen microaerobically. Growth occurs well in the presence of ammonium, but nitrate is not reduced. In absence of yeast extract, strains can utilize different carbon sources such as D-galactose, D-xylose, D-fructose, Darabinose, D-mannitol, D-sorbitol, and grow on $30 \%$ sucrose and $30 \%$ glucose. Dihydroxyacetone is produced from glycerol and $\gamma$-pyrone from D-glucose. Ethanol is oxidized to acetic acid, and acetate and lactate over oxidize to $\mathrm{CO}_{2}$ and water. Methanol is not utilized. Single amino acids like L-alanine, L-cysteine and L-phenylalanine can be used as a sole source of carbon and nitrogen. L-Threonine is not utilized as the sole source of carbon and nitrogen. The ubiquinone present is of the type Q-9 and DNA G +C content is $64 \cdot 1 \mathrm{~mol} \%$. Based on data from the MLEE assay along with DNA-DNA relatedness and nifH gene sequence, the type strain $\mathrm{RG1}^{\mathrm{T}}$ can be differentiated from other Acetobacter species.
The type strain is strain $\mathrm{RG}^{\mathrm{T}}$ (= MTCC $6912^{\mathrm{T}}=\mathrm{LMG}$ $23498^{\mathrm{T}}$ ), isolated from Kombucha tea.

\section{Acknowledgements}

We thank Dr Encarna Velázquez for promptly sending us A. oeni $\mathrm{B} 13^{\mathrm{T}}$ as a gift and Dr Dhritiman Ghosh for help in the phylogenetic analysis. Work was partially supported from funding agencies of the Government of India: CSIR (no. 38/1097/04/EMR-II) and DBT (no. BT/PR5111/BCE/08/340/2004). Financial support was also received from Jadavpur University to D. D. and R. G.

\section{References}

Blanc, P. J. (1996). Characterization of the tea fungus metabolites. Biotechnol Lett 18, 139-142.

Caballero-Mellado, J. \& Martínez-Romero, E. (1994). Limited genetic diversity in the endophytic sugarcane bacterium Acetobacter diazotrphicus. Appl Environ Micrbiol 60, 1532-1537.

Caballero-Mellado, J., Fuentes-Ramírez, L. E., Reis, V. M. \& Martínez-Romero, E. (1995). Genetic structure of Acetobacter diazotrophicus populations and identification of a new genetically distant group. Appl Environ Microbiol 61, 3008-3013.

Cavalcante, V. \& Döbereiner, J. (1988). A new acid tolerant nitrogen-fixing bacterium associated with the sugarcane. Plant Soil 108, 23-31.

Cleenwerck, I., Vandemeulebroecke, K., Janssens, D. \& Swings, J. (2002). Re-examination of the genus Acetobacter, with descriptions of Acetobacter cerevisiae sp. nov. and Acetobacter malorum sp. nov. Int J Syst Evol Microbiol 52, 1551-1558.

Felsenstein, J. (1985). Confidence limits on phylogenies: an approach using the bootstrap. Evolution 39, 783-791.

Fox, G. E., Wisotzkey, J. D. \& Jurtshuk, P., Jr (1992). How close is close: $16 \mathrm{~S}$ rRNA sequence identity may not be sufficient to guarantee species identity. Int J Syst Bacteriol 42, 166-170.

Franke, I. J., Fegan, M., Hayward, A. C. \& Sly, L. I. (1998). Nucleotide sequence of the nifH gene coding for nitrogen reductase in the acetic acid bacterium Acetobacter diazotrophicus. Lett Appl Microbiol 26, $12-16$.

Fuentes-Ramírez, L. E., Bustillos-Cristales, R., Tapia-Hernandez, A., Jimenez-Salgado, T., Wang, E. T., Martínez-Romero, E. \& Caballero-Mellado, J. (2001). Novel nitrogen-fixing acetic acid bacteria, Gluconacetobacter johannae sp. nov. and Gluconacetobacter azotocaptans sp. nov., associated with coffee plants. Int J Syst Evol Microbiol 51, 1305-1314.

Jimenez-Salgado, T., Fuentes-Ramírez, L. E., Tapia-Herńandez, A., Mascarúa-Esparza, M. A., Martínez-Romero, E. \& CaballeroMellado, J. (1997). Coffea arabica L., a new host plant for Acetobacter diazotrophicus, and isolation of other nitrogen-fixing Acetobacteria. Appl Environ Microbiol 63, 3676-3683.

Jojima, Y., Mihara, Y., Suzuki, S., Yokozeki, K., Yamanaka, S. \& Fudou, R. (2004). Saccharibacter floricola gen. nov., sp. nov., a novel osmophilic acetic acid bacterium isolated from pollen. Int J Syst Evol Microbiol 54, 2263-2267.

Kumar, S., Tamura, K. \& Nei, M. (2004). MEGA3: integrated software for molecular evolutionary genetics analysis and sequence alignment. Brief Bioinform 5, 150-163.

Labrenz, M., Tindall, B. J., Lawson, P. A., Collins, M. D., Schumann, P. \& Hirsch, P. (2000). Staleya guttiformis gen. nov., sp. nov., and Sulfitobacter brevis sp. nov., $\alpha-3$-Proteobacteria from hypersaline, 
heliothermal and meromictic Antarctic Ekho Lake. Int J Syst Evol Microbiol 50, 303-313.

Lisdiyanti, P., Kawasaki, H., Seki, T., Yamada, Y., Uchimura, T. \& Komagata, K. (2000). Systematic study of the genus Acetobacter with descriptions of Acetobacter indonesiensis sp. nov., Acetobacter tropicalis sp. nov., Acetobacter orleanensis (Henneberg 1906) comb. nov., Acetobacter lovaniensis (Frateur 1950) comb. nov., and Acetobacter estunensis (Carr 1958) comb. nov. J Gen Appl Microbiol 46, 147-165.

Lisdiyanti, P., Kawasaki, H., Seki, T., Yamada, Y., Uchimura, T. \& Komagata, K. (2001). Identification of Acetobacter strains isolated from Indonesian sources, and proposals of Acetobacter syzygii sp. nov., Acetobacter cibinongensis sp. nov., and Acetobacter orientalis sp. nov. J Gen Appl Microbiol 47, 119-131.

Lisdiyanti, P., Kawasaki, H., Widyastuti, Y., Saono, S., Seki, T., Yamada, Y., Uchimura, T. \& Komagata, K. (2002). Kozakia baliensis gen. nov., sp. nov., a novel acetic acid bacterium in the $\alpha$-Proteobacteria. Int J Syst Evol Microbiol 52, 813-818.

Loganathan, P. \& Nair, S. (2004). Swaminathania salitolerans gen. nov., sp. nov., a salt-tolerant, nitrogen-fixing and phosphatesolubilizing bacterium from wild rice (Porteresia coarctata Tateoka). Int J Syst Evol Microbiol 54, 1185-1190.

Lu, S.-F., Lee, F.-L. \& Chen, H.-K. (1999). A thermotolerant and high acetic-acid producing bacterium Acetobacter sp. 114-2. J Appl Microbiol 86, 55-62.

Musser, J. M., Bemis, D. A., Ishikawa, H. \& Selander, R. K. (1987). Clonal diversity and host distribution in Bordetella bronchiseptica. J Bacteriol 169, 2793-2803.

Muthukumarasamy, R., Revathi, G., Seshadri, S. \& Lakshminarsimhan, C. (2002). Gluconacetobacter diazotrophicus (syn. Acetobacter diazotrophicus), a promising diazotrophic endophyte in tropics. Current Science 83, 137-145.

Muthukumarasamy, R., Cleenwerck, I., Revathi, G. \& 8 other authors (2005). Natural association of Gluconacetobacter diazotrophicus and diazotrophic Acetobacter peroxydans with wetland rice. Syst Appl Microbiol 28, 277-286.
Selander, R. K., McKinney, R. M., Whittam, T. S., Bibb, W. F., Brenner, D. J., Nolte, F. S. \& Pattison, P. E. (1985). Genetic structures of populations of Legionella pneumophila. J Bacteriol 163, 1021-1037.

Selander, R. K., Caugant, D. A., Ochman, H., Musser, J. M., Gilmour, M. N. \& Whittam, T. S. (1986). Methods in multilocus enzyme electrophoresis for bacterial population genetics and systematics. Appl Environ Microbiol 51, 873-884.

Silva, L. R., Cleenwerck, I., Rivas, R., Swings, J., Trujillo, M. E., Willems, A. \& Velázquez, E. (2006). Acetobacter oeni sp. nov., isolated from spoiled red wine. Int J Syst Evol Microbiol 56, 21-24.

Sokollek, S. J., Hertel, C. \& Hammes, W. P. (1998). Description of Acetobacter oboediens sp nov. and Acetobacter pomorum sp nov., two new species isolated from industrial vinegar fermentations. Int J Syst Bacteriol 48, 935-940.

Stackebrandt, E. \& Goebel, B. M. (1994). Taxonomic note: a place for DNA-DNA reassociation and 16S rRNA sequence analysis in the present species definition in bacteriology. Int J Syst Bacteriol 44, 846-849.

Stal, L. J. (1988). Nitrogen fixation in cyanobacterial mats. Methods Enzymology 167, 475-484.

Thompson, J. D., Higgins, D. G. \& Gibson, T. J. (1994). CLUSTAL W: improving the sensitivity of progressive multiple sequence alignment through sequence weighting, position specific gap penalties and weight matrix choice. Nucleic Acids Res 22, 4673-4680.

Weisburg, W. G., Barns, S. M., Pelletier, D. A. \& Lane, D. J. (1991). $16 \mathrm{~S}$ ribosomal DNA amplification for phylogenetic study. J Bacteriol 173, 697-703.

Yamada, Y., Hoshino, K. \& Ishikawa, T. (1997). The phylogeny of acetic acid bacteria based on the partial sequences of $16 \mathrm{~S}$ ribosomal RNA: the elevation of the subgenus Gluconacetobacter to the generic level. Biosci Biotechnol Biochem 61, 1244-1251.

Yamada, Y., Katsura, K., Kawasaki, H., Widyastuti, Y., Saono, S., Seki, T., Uchimura, T. \& Komagata, K. (2000). Asaia bogorensis gen. nov., sp. nov., an unusual acetic acid bacterium in the $\alpha$-Proteobacteria. Int J Syst Evol Microbiol 50, 823-829. 